\title{
BEING FEMALE DOING GENDER. \\ NARRATIVES OF WOMEN IN EDUCATION \\ MANAGEMENT.
}

(Approx. words: 8000)

\section{Vincenza Priola}

Address for correspondence: School of Economic and Management Studies, Darwin Building, Keele University, Keele, Staffordshire, ST5 5BG, United Kingdom, Tel. 0044 (0)1782 583622, Fax. 0044 (0)1782 584277,Email: V.Priola@mngt.keele.ac.uk 


\title{
Being Female Doing Gender. Narratives of Women in Education Management
}

\begin{abstract}
The paper explores gender relations in academia and discusses how gender is constructed within academic institutions. It is based upon the study of a business school, part of a British university. The construction of gender relations within this institution was of special interest because the majority of managerial roles were occupied by women. All female academicmanagers (Dean, Associate Deans and Heads of Department) and a random selection of female and male academics were interviewed. The process of construction of gender relations is investigated through the analysis of the discrepancy between the 'masculine culture' of high education institutions and the dominance of women managers within this organisation. It is suggested that the numerical dominance of women managers may create tensions between their individual identities as women and their managerial identities, due to the predominance of masculine practices and values within the organisation. Additionally, it emerged that the maintenance of masculine ideals and practices is also associated with downplaying women's achievements.
\end{abstract}

Key words: gender, femininities, education management, identities, higher education.

\section{Introduction}

Research on gendering management has acknowledged the centrality of the gender substructure in understanding organisational functioning (e.g. Mills and Tancred, 1992; Gherardi, 1995; Alvesson and Billing 1997; Alvesson, 1998). The gender dimension of 
organisations is seen as fundamental in determining its activities, organisation processes are gendered processes and shape relations at all levels (e.g. Kanter, 1989; Calas and Smircich, 1992). 'It matters a great deal whether organisational employees are female or male' (Mills and Tancred, 1992: 1) because their gendered positions influence the process of creation and negotiation of their own individual identity and the identity of their subordinates and superiors within the workplace. Women managers in organisations face issues characterised by the need to shape women's positions in roles traditionally occupied by men. Women in higher education find themselves fighting a very traditional and masculine culture (ElKhawas, 1997) and experiencing structural changes in the role of university education and its management processes.

This paper explores the ways in which the gender of education managers (in this case female) shapes the gendered processes in academia, which, as documented in existing literature (e.g. Barry et al, 2001; Thomas and Davies, 2002; Deem, 2003), is predominantly associated with masculine discourses and practices. Drawing on poststructuralist understanding of identity and gendered subjectivities, the paper discusses emotional dimensions, tensions and ambiguities which may be experienced by women academics who choose the managerial career path in higher education. Poststructuralist feminism (e.g. Irigaray, 1985; Hekman, 1992; Ossen, 1997) focuses on the ways in which gender identities and subjectivities are socially constructed, rejecting the categorisation of women as homogeneous group and the view that femininity and femaleness are unitary conceptions. From this perspective, identities and subjectivities are both unstable, contingent and precarious. 'Identity acquires the status of a 'project' to be constantly worked at, to be accomplished or achieved' (Kerfoot and Knights, 1998: 12).

This paper has two main aims. Firstly, it has the broad aim of exploring gender relations in academia. Various authors have expressed concerns (e.g. Whitehead, 2001, Thomas and Davies, 2002) that women are becoming more marginalized in the market-driven culture 
characterising education, a public service that has been subject to 'accusation of elitism, social engineering, exclusion and male dominance' (Whitehead, 2001: 85). In view of these concerns, this study focuses on a British business school, which is part of a 'new' ${ }^{1}$ university. This school was chosen because it is characterised by a high percentage of women holding management positions. The school does not represent the situation in British universities where the majority of executives are men. In fact, it does not even represent the university to which it belongs, where only two out of ten schools are headed by women: the business school and a traditionally-oriented female school.

The second aim of the paper is to explore the influence that the construction of gendered processes and identities within this institution, has on how women managers relate to managerialist and masculinist organisational practices. In doing so, the possible tensions between women as 'feminine' and their managerial identities are discussed. Academics' narratives are also analysed to explore whether and how these women academic-managers are commencing a process of feminisation ${ }^{2}$ (Fondas, 1997) within a traditionally and profoundly masculine organisation.

The paper is organised as follows. Firstly, it focuses on key concerns identified in the gender literature and associated with education management. Secondly, it discusses the higher education context in the UK with reference to the process of new-managerialism. Thirdly, it provides an analysis of the case study data. Here, the tensions and ambiguities associated with both the gendered processes and the identity work experienced by the academic-managers and the academic staff are explored. The paper concludes by raising some issues in light of the emerged tensions and ambiguities created by the dominance of women managers. 


\section{Gender in Education Management}

Masculine and feminine identities are produced by negotiating gender differences. Gherardi (1994: 607) suggests that 'we do gender while we work, while we produce our office organisational culture with its meanings of what is fair in the relationship between the sexes and what is not'. The meaning of gender is negotiated in everyday interactions, however, it is permeated by cultural norms. Poststructuralist feminist studies on femininities and masculinities at work (e.g. Kerfoot and Knights, 1993, 1996, 1998; Alvesson, 1998) have highlighted that contemporary market-driven organisations reinforce forms of masculine management in which managers disengage, denying their emotions in order to obtain control over themselves, the others and the environment (Collinson and Hearn, 1996; Kerfoot, 2000). Kerfoot and Knights (1998: 8) acknowledge that 'what distinguishes masculine identities is the instrumental pursuit of the control of social relations'.

The female proportion in managerial roles (particularly at lower-middle level) may increase but this does not necessarily determine a change in institutional practices. Working practices and the construction of workers' identities are influenced by the dominant culture (Priola, 2004). The academic profession has shown resistance to cultural change and the position of women in academic institutions is evidence of this (Spurling, 1997). Miller (1994) suggests that the most obvious feature of the management of universities is not only the dominance of men but also the dominance of masculine styles. Reflecting the numerical dominance of men are masculine imageries, discourses and practices that often pervades the managerial function and the perception of it (Collinson and Hearn, 1996). Similarly, Spurling (1997) comments that established academic conventions result in the gender imbalance in favour of masculine experience and criteria in the curriculum, in ways of working and in staffing. The gender dimension of organisational life also results in the assessments of 'fit', which are based on a male rather than a female profile, with negative consequences for perceptions of women's 
suitability for managerial positions (Harris, 1998). 'Women 'fail' to gain inclusion because they are judged in systems set up by men reflecting male standards and criteria' (Oakley, 2001: xii). Whitehead (2001) emphasises that the shifting culture of education towards a more entrepreneurial, managerialist culture may reduce the equal opportunities discourse to marketing rhetoric and strengthen the gendered culture in favour of those men prepared to adopt more aggressive approaches to management. This process may create even greater tensions for those women who choose to test themselves as managers and want to succeed in masculine organisations.

Blackmore (1996: 345) suggests that 'gendered power relations in the context of restructuring during the 1990s has led to a re-gendering of the education market'. This can be seen as the re-masculinisation of the core activities and the formation of a 'flexible peripheral labour of feminised, casualised and deprofessionalised teaching force'. Many academic women say that they are under pressure to accept a heavier teaching load and more pastoral care than their male colleagues who can focus more on research and external networking (Thomas and Davies, 2002). Teaching is seen to fit family life better than research and women are still expected to bear the major responsibility for the care of children (Spurling, 1997). However, research has always dominated the professional image of the academic, it is the 'central professional endeavour and the focus of academic life' (Rice, 1992: 119). This determines a depreciation of many women's work in academic institutions, where academic women are traditionally published less than academic men (Brooks, 2001).

Blackmore and Sachs (2001) interviewed more than 50 women academics who hold leadership positions in Australian universities ${ }^{3}$. They found that academic work is moving towards 'competitivism' and that it has intensified across all the domains of research, teaching, administration and service in marketing the institution. Institutional practices which highlight corporate managerialism, such as enterpreneurialism, paternalism, careerism and 
informalism are interconnected with masculinities (Collinson and Hearn, 1994) and contribute to the resistance of the academic masculine culture.

The academic environment appears to be characterised by a traditional and specific masculine culture, or as Hearn (2001) suggests, by different forms of 'specific masculinities' and by more general masculine criteria imported from the corporate world. The interconnection of these aspects sees women disadvantaged on both career paths: the research and the management paths. 'The superior weight given to masculine criteria, thoroughly embedded in the human and intellectual environment of the institutions, exerts as powerful an influence by example and implication as anything explicitly stated' (Spurling, 1997: 39).

Spurling (1997) acknowledged that women in senior posts in traditional and new universities reported similar experience of gender imbalance but attributed it to different causes. Women in new universities identified 'machismo of the business culture' as the underlying reason for this imbalance, while women in traditional universities referred to a specific academic machismo'. Prichard (1996: 230) suggests that in the 'new' universities, as compared to traditional universities, it is more common to find groups of women (and men) who are challenging taken for granted masculine ways of doing and being. It is also the case that, for cultural and historical reasons, the new universities employ more women in senior positions than traditional universities (Thomas and Davies, 2002). In the UK, the first woman vicechancellor was appointed in a new university. It was not until 1995 that a woman was appointed vice-chancellor of a traditional university. The higher the status of the university, the more male academics are likely to work there (Hearn, 2001). Kerman (1995) suggests that women not only have to show outstanding abilities to be appointed to senior management positions in universities, but that they also must not be seen as a threat in terms of management style and subject identity. Oakley (2001: xii) points out that ease of communication in bureaucratic organisations such as academic institutions, 'is promoted by 
limiting managerial jobs to those who are socially homogeneous' and that 'male homosociability is therefore fundamental to the system'.

\section{The Research Context: Higher Education in the United Kingdom}

The state of academia currently reflects the influence of two drives: the move towards the importance of management and private-sector practices (Leonard, 1998; Deem, 2003) and the reduction and shifting of state funding. In recent decades, universities have progressively moved towards a market driven culture which has informed their management processes (Willmott, 1995). This 'market driven culture' has translated in increasing marketisation (Ball, 1990; Kenway, 1995), in the introduction of new managerialism (Thomas and Davis, 2002; Leathwood, 2005) and in an increasing emphasis on accountability (Brook, 2001; Barry et al., 2001). Prichard (1996: 229) notes that from being administrators of largely predictable and protected funds, senior post-holders in universities are now under pressure to take responsibility for the processes that influence these funds. Institutions are considered as businesses, their heads are business managers and the students are customers. The emphasis has shifted from 'intrinsic reward' to measurable outcomes in terms of research grants and publications (Brooks, 2001), teaching quality and in terms of income generation (see Parker and Jary, 1995). The shift to a managerial approach is also evident in the funding mechanisms and the systems of measurement (e.g. RAE, QAA etc.), in the language and in the systems of control and accountability (e.g. appraisal systems, performance indicators).

Evidence of these trends can also be seen in this study where the academic-managers emphasise productivity, the need to maximise resources and the requirement to offer 'popular' as well as distinctive programmes. When asked which were the most important aspects of her job as a university 'manager', one of the participants stated: 
'The most important part of my job is the business side, whether it works, the revenue, the offer of good products and services. The objective is to have Undergraduate and Graduates who feel proud to be here; have a happy ship, people that enjoy what they are doing, that see how their activities fit. An important aspect is to have people who move on, who are self-confident, comfortable.' (Susan, Associate Dean)

It has to be underlined that this interviewee works for a new university. New universities, as compared to traditional universities, have historically placed greater emphasis on managerialism. This is currently aggravated by the lower amount of financial resources made available from the university funding councils. As highlighted by another participant:

\footnotetext{
'It started at the beginning of the 90s and in a very short time the school has changed tremendously. We did not have so many activities going on. We were a polytechnic with funding coming from local authorities, now we are a university and we work like a business, we need to make our money, we need to engage in activities which are profitable.' (Cheryl, Head of Department)
}

This shift toward managerialism co-exists in parallel with the persistence of a traditional culture based on bureaucratic hierarchical systems founded on sets of values that depend upon a particular configuration of gender relations (Ferguson, 1984; Leathwood, 2005), exacerbated by the maintenance of homogeneity. The persistence of a masculine culture in higher education institutions may explain the difficulties women face in gaining top positions (both at managerial level and professorial level). This paper focuses on higher education in the UK, however this inequality is reflected in universities globally. A UNESCO report Women in Higher Education Management (cited in Dines, 1993) states that 'the global picture is one of men outnumbering women at about five to one at middle management level and about twenty or more to one at senior management level'. Only seven per cent of universities worldwide are led by women (Munford and Rumball, 1999). 
While this suggests a disadvantaged situation for women in senior positions, overall the number of female academics is approximately $35 \%$ of the total number of academics in the UK (as shown in the table below).

\section{[TABLE 1 HERE]}

The gap in gender distribution is compounded by a gap between female and male salaries. The gap in salary reflects a difference in the status/positions occupied by women and men, which sees the majority of women employed in junior positions and men dominant in senior roles (in professorial and managerial levels).

\section{[TABLE 2 HERE]}

The sections that follow discuss the discourses emerging from the analysis of the case study material and how women academic-managers influence and are influenced by the gendering processes at this institution. 


\section{Doing Gender Doing Education: The Study}

The study is based on a series of in-depth interviews with academic-managers and academic staff at a Business School in the UK. This school reflects a division of labour typical of other academic institutions. Most of the administrative support staff are women and approximately two thirds of the academic staff are men. However, the majority of the executives are women: the Dean of the school, two of the three Associate Deans and two out of four Heads of Department are women. Also, the Head of Learning and Teaching and the Head of Academic Development are women ${ }^{4}$. The methodological approach consisted of: (a) semi-structured interviews with all women who held managerial positions within the school (5); (b) informal un-structured interviews with academic staff (15 men and women); (c) participant observation of the organisation's working environment and climate. The interviews with the women academic-managers lasted for approximately one hour. The interviews with the other academics varied in length.

The interview transcripts and the research notes were approached in two ways. Firstly, in order to highlight the influence that the high presence of women managers may have on the gender relations at this institution, transcripts were analysed to search for emerging discourses (and themes) broadly associated with the management of gender relations. Secondly, data were analysed to highlight women managers' identity work, in relation to the construction of their managerial subject position and their feminine identities. The study of these processes will highlight any tension and/or conflict that the masculinity of the institution may determine on women's identities processes. It will also draw attention to whether the presence of women managers is challenging the long established culture of academia and creating a more feminine working environment (Goode and Bagilhole, 1998; Barry et al., 2001). 


\section{Managing Gender}

The appointment of the female Dean seems to have changed the perception of women's work within the school. According to an interviewee ${ }^{5}$ :

'The business school has changed since Mary arrived, prior to her arrival there was prejudice against women. It was not in the open but, for example, there was the perception that women had to take minutes at meetings and organise the work. There were a few women in senior positions but there was always the thing 'you have family commitments'. It was not said aloud but there was resistance to give full responsibility. I was not involved in the management decisions, I was allowed in the discussion when things were not going well. Once, at a ceremony, I met the old Dean when he had already left and he admitted that he mostly ignored my contribution. I don't know if this is because I was a woman or because I was heading the Undergraduate programmes. At that time, the focus was on Postgraduate and professional programmes and the Undergraduate programmes were mainly ignored. However, there were prejudiced comments, for example, after a long meeting in the evening, if I said 'I am glad to go home' the likely response was 'oh yes, you have to make tea now'.' (Susan, Associate Dean)

Before the appointment of the Dean, women's contribution to the management of the school was limited. Even though one of the associate deans was a woman, she felt isolated, as the head of programmes which, at that time, were not the focus of the school's activities. She felt that the general perception of women's work was connected with certain positions within the workplace (e.g. secretarial and administrative) and with a carer role within one's family. However, while the Associate Dean suggests that there are no longer 'prejudices' against women and that there is a more democratic sharing of power among the management group, another participant has a different view. She perceives the hostility of male colleagues against successful women and suggests that they do not recognise that women may obtain a job on the basis of their merit but because the Dean is a woman.

'When I applied for this job I was a PL already but I had never been a Head of Department. I was told that I would have been fine because Mary employs only women. They don't believe you are there for your own merit but because Mary is a woman. 
Interviewer: Is it correct that she has mostly employed women? $\underline{C}$ : Yes mainly, but I strongly believe that she employs the candidate on the basis of merit but the men here don't see that.' (Cheryl, Head of Department)

This view is confirmed by a male academic who interprets the appointments made by the Dean as favouritism towards women. He suggested that the Dean encourages and supports women more than she supports men and that she prefers to work with women rather than with men. During the interview, he said: 'She treats women better; they have greater chances of promotion. As a man I have greater difficulties here'.

On the whole, it seems that a move toward a more balanced gender distribution does not always correspond to the perception of gender equality. It seems that the increasing employment of women is seen differently by female and male academics. It appears that male staff reclaim the masculinity of their workplace by downplaying women's achievement, because they have been selected, managed and promoted by women.

It is worth noting that the majority of men at this school have been employed since the university was a polytechnic. One of the interviewees refers to the divide between the old people and the new people, the old culture and an evolving working environment. She also associates the old people and the old culture with her male colleagues because until the late 1980s very few women were employed as academics.

'I think it is difficult for the Dean being a woman here because there are still too many people from the old school and they still hang on to the old culture of the place. For me to avoid the people with the old mentality destroying the good work, I have to run the department, the programmes, do the teaching. The new people were selected recently and I cannot give them the task of running programmes. I don't want the old people, the men, to do it because I know that their mentality would destroy all the work I have done as a deputy and then as a head, particularly to integrate the two areas of the department.' (Linda, Head of Department) 
Here, it emerges that most men are considered as having an old mentality and hanging on to the old culture of the 'previous school'. The men in this department have been employed for a long time and have been in the majority. Only recently, more women have been employed, allowing the department to achieve a more balanced gender distribution. The long serving men are attributed an old mentality which seems in conflict with the new directions taken by the Dean and some other members of the school management team. In order to overcome this old 'mentality', Linda has chosen the strategy of doing most of the work herself rather than actively working toward changing the culture. However, from the transcripts it is not clear whether her approach is the result of a past failed attempt to change this attitude or her usual tendency. This propensity for avoiding open challenges is shared by the Dean who recognises that her management style tends to deliberately avoid conflict for a more amenable approach.

\footnotetext{
'I believe is better to focus with those who are willing to come with you rather than challenging resistance. My style is knocking on open doors and pushing from behind because I believe it is the most effective way of changing a culture rather than creating open conflicts. ... I am willing to take on tough issues more than men, I think, and I am not confrontational, but this has to do with age more than gender.' (Mary, Dean)
}

Some may argue that behind this statement there is greater emphasis on a feminine attitude in dealing with disagreement, avoiding open conflicts and creating cooperation. The Dean suggests that this attitude has developed with age and it is not related to her gender. However, she implies that men tend to avoid complex issues, proposing the willingness to tackle and solve difficult problems as an aspect which contributes to the construction of her gender identity.

Gherardi (1994) argues that femininity and masculinity, while socially constructed, represent a binary opposition in which the feminine part is subordinate, suppressed, seen as weak and powerless (see also Kerfoot and Knights, 1998). To explore this aspect within this organisation, the response of Cheryl below represents a good example of how organisation 
members manage this duality. The participant refers to the event in which she was appointed Head of Department following her (male) colleague’s resignation.

\begin{abstract}
'I realised that there were differences in people's behaviour here in the department when I was taking on the role. I've got the feeling that some of the men thought that I could not cope from an emotional point of view. Because of what happened with the previous head and the problems there were with the department many had doubts, but I think that in the case of the colleague who stepped down there were objective reasons for not coping. In my case, I perceived that they thought I could not cope emotionally. This makes me more determined. I don't want to be seen as soft, it is almost like it is a shame for me to show that I could be soft. Male traits are perceived better.' (Cheryl, Head of Department)
\end{abstract}

This interviewee reinforces the dualism masculine/feminine, positive/negative, strong/weak and gains determination by showing the possession of what she defines as male traits. This position strengthens the process of de-valuation of the feminine and confirms the view of many philosophers who have emphasised the impossibility of a positive definition of the feminine (e.g. Kristeva, 1981).

The woman manager is defined as a specific gendered subject position by the contingently determined context. When men have difficulties in their job, these tend to be interpreted (both by men and women) as determined by 'objective’ reasons. For a woman, it becomes difficult to manage a problematic situation because her subject position is seen as feminine, thus soft, weak and emotional. The managerial subject position is associated with rational and competitive discourses (thus masculine). The woman manager subject position is therefore constantly constructed and re-constructed in a process which often determines contradictory positions, tensions and displacement.

The identity work undertaken by this interviewee reifies the discourses of rationality, instrumentality and control associated with the subject position of the 'manager'. However, this enacted way of approaching her professional role and its power relations contrasts with 
her gender role as constructed by herself and others. Such identity investment may determine a contradictory position, in which the individual's own sense of being and identity is not easily achieved and in which a woman manager's position is that of the 'outsider on the inside' (Gherardi, 1996). 'The identity of such a multiple and contradictory subject is therefore always contingent and precarious, temporarily fixed at the intersection of those subject positions and dependent upon specific forms of identification' (Mouffe, 1995: 372). Evidence of the emerging contradictions between Cheryl's positions as a manager, as a woman and as a subordinate can also be inferred by reading her contributions in the two subsequent sections.

\section{Women Managers and Gender Symbolism}

The 'traditional' gender division of work has lead to various forms of gender symbolism. One of these is linked to the management style of men and women. Korabik (1990) suggests that men and women do not differ in their management approach because women managers are a highly selected group who do not conform with feminine values. Management and leadership have traditionally been predominantly male territory, thus the figure of the ideal manager is grounded in masculine values (Middlehurst, 1997). Masculine discourses and practices are so dominant that they have to be embraced if a person seeks to have any influence as a manager (Kerfoot and Knights, 1998). This may affect both women's career choice and the decisions made by other managers in selecting and promoting women who show the requisite levels of masculinity (Korabik and Ayman, 1989). However, as feminist theorists suggest (Marshall, 1984, 1995; Walby, 1986; Witz, 1992), women's relationship to management and organisation often generates conflicts and tensions over gender roles, power relations, sexuality, forms of resistance and the masculine aspects of the professional culture (Whitehead, 2001).

A female member of staff at this business school noted that, before joining the school, she had never worked for a woman and she had always found it comfortable to work for a man. 
Although sensitive to gender issues, she could not avoid feeling apprehensive by the idea of having a female Head of Department and a female Dean. The symbolism of the aggressive/masculine woman had been so powerful to have influenced her expectations.

'When I was invited for the interview, I was pleased that both the Dean and the Head of the department were women because it showed something positive about the place. However, I was also intimidated because often women in top positions are much tougher than men' (a female academic).

The view of competitive, aggressive women that mock men and adopt masculine behaviours and values has also been influenced by the 1980s 'power-dressed women executives' US culture. The wave of advertising, films, observations and biographies of women executives showed that women 'dressed for success' by 'aping' men and that women at the top were strong and tough (Doyle Walton, 1997). This image not only influenced men's perception but also other women's views. Powney (1997: 51) suggests that commonly held attitudes that prejudice the appointment of women to senior management positions include the following:

- Women seem incongruous in occupations where we are accustomed to seeing men.

- It is asserted that men would not want to work for a female boss.

- It is argued that women also prefer to have a man rather than a woman in authority.

Both men and women would prefer to work for a man, only a positive experience of having a woman manager seems to change this view. One of the heads of department interviewed explains her reasons for preferring a male boss:

'I don't like working for women, I prefer to work for men. Women are generally more bossy, I feel that they need to be tougher than men and very often they don't help other women. Generally women slag other women off. This is not only the case at work but in all aspects of life. If a man is having an affair is always the fault of another woman never the man's. Here, the men complain about each other but they come together when they 
need to. Men in general create a network of support with each other, women never do that, we are generally more isolated and often are very critical with each other.' (Cheryl, Head of Department)

The interviewee refers to two important aspects. The first highlights the need of women to enact masculine ways to approach work and work relationships. The second refers to an important issue concerned with the difficulties many women experience in working with other women. Spurling (1997) reports findings from a series of interviews with senior academics in the UK. Some of the women she interviewed commented on the behaviour of female colleagues who spend time and energy arguing why suggestions would not work rather than helping to identify and implement possible improvements. They displayed 'individual intellectual machismo' of the type 'my argument is stronger than yours' undermining the efforts of colleagues. For many of those women who adopt masculine values and practices, their working lives constitute a continuous struggle to manage their position as managers and their feminine identities. 'The uniqueness of women in such positions of prominence made them both isolated and visible. For many the loneliness and a feeling of being a stranger in a strange land were the costs of their success' (King, 1997: 92).

Increasingly, women (and men) are acknowledging different ways of managing. However, in order to challenge existing norms and make changes women have to 'learn to play by the rules' and seek support and role models. From male academics, women need to learn the importance of networking and mutual support. One important aspect, which appears to influence one's success, is the mentoring process ${ }^{6}$. The Dean interviewed for this research, acknowledged the strong influence that her mentor (an established female professor at the institution where she started her academic career) had on her career. A problem for some women who seek out a mentor is that there are few other women senior enough in the profession to provide support and to encourage access to career opportunities (Powney, 1997). Doyle Walton (1997) reports the acknowledgement by a retired vice-chancellor of Cambridge and a Cambridge principal of the importance of a women's network. It appears 
fundamental for women's success that they work together, help each other, setting up a network to offer guidance, role modelling, support and sharing of information ${ }^{7}$.

\section{A 'masculine' organisation managed by women}

It has been discussed in previous sections that in academia 'masculine values' are predominant. From this case study, it has emerged that gender repression exists even in this organisation managed by women. However, the dynamics that emerged suggest that this repression manifests itself in different ways, often in covert forms. The image that has been produced is one in which aspects of femininities, as highlighted by the female managers and some academics (e.g. women managers are more supportive), coexist alongside dominant and pronounced masculinities (e.g. a defined hierarchical structure, women who do not want to show their emotions). One of the interviewees recognises that the school does not have a feminine culture, even though it is mainly managed by women. She does not perceive feminine aspects (e.g. closeness, nurturing, caring) in its activities and she attributes this to the environment of higher education which is permeated by masculine values. She also suggests that when less resources are available to an institution, the climate becomes harsher (thus more masculine).

'Even though the majority of the executives are women it is not a feminine culture. There is not closeness or nurturing and caring. But this is not the gender of higher education, which is masculine. Generally it is a hostile environment and in the uni we are is harsher. Given all the constraints on us it is very difficult. I have worked in other places and you see that the less resources available the harsher it is. Here, there is a managerial culture which focus on efficiency not effectiveness and this is related to the resources. The further you go down the league table, more emphasis is placed on efficiency as opposed to effectiveness.' (Jo, Associate Dean)

While admitting that overall people felt supported by managers and colleagues, another interviewee recognised that it is not a particularly nurturing and collegial environment. She suggests that more cooperation and encouragement is needed, denying the possibility that the 
high concentration of women academic-managers has had an impact on the gender dimension of the institution.

'This place needs more stroking and we don't get enough. People here are scared of Mary, she is unpredictable, we have to keep the guard up because you don't know what to expect. Maybe she thinks that is a good thing but I actually find that it is the opposite that works, the encouragement, the recognition, the steady support, at least in the long term. ' (Cheryl, Head of Department)

On the whole, while a certain level of support and care has been recognised by the participants, the school does not show a feminine orientation. Expressing feelings and emotions is perceived as weak and negative. In masculine occupations such as managerial jobs people have to be 'cool, impassive or stern' (Cockburn, 1991: 150) and this case is not exceptional. The academic-managers at this institution present themselves as supportive and thoughtful but efficient, rational and firm. To some members of the staff, the top management team appears considerate but bureaucratic, goal driven, controlling and distant. The suggestion of the interviewee above that the Dean may be unpredictable and that one needs to 'keep the guard up', may also give an insight into the contrasting and contesting identity work of someone, who may want to be caring and supportive, but is afraid of loosing the control and authority over people. The Dean, during the interview also stated that 'to make changes it means more control' and that some people see her as extremely controlling.

\section{Family and Femininities}

A discussion on women and work cannot be complete without the consideration of the implications of women's (and men's) family life on their career. Historically, women have always assumed greater responsibility for the care of the family and the household. Currently, this is still expected of them regardless of any career ambition (Thomas and Davies, 2002). Powney (1997) suggests that often men do not have to consider home affairs because someone else is running the home for them. When this is not so, they do not admit the 
constraints of their personal life because they think it may reduce their stature. Examination of the interview transcripts revealed a common theme: all of the interviewees have commented on the difficulties in combining the care of children and the family with a career. However, it is interesting that only two of the academic-managers interviewed have children and these did not consider their family an obstacle to their career progression. The analysis of the contributions of the women academic-managers who do not have children highlights an important aspect related to the perceptions of their jobs. All of them, in fact, suggested that they could not do their job while having a family.

\footnotetext{
'I admire people who have family and I ask myself how they do it. I am single so for me this is not an issue. However, I don't want to spend my life here while the rest of them are somewhere else enjoying themselves. I don't know how people with children do it because women see things through and it takes time and effort and it needs a lot of support at home. Here, if you look at women in management positions who have children, Linda is leaving and, of the others, only Susan has children. She is very good at her job and very thorough, she must have a lot of support. I know she has support from her husband. In most cases for women with a career, the husband's career has to step down for the wife's because it is so difficult for both to have careers and children.' (Cheryl, Head of Department)
}

Two points are worth noting in the excerpt above. The interviewee suggests that combining a career with the care of children is more difficult for women than it is for men, because of the feminine attitude of being thorough and meticulous at their jobs. While admitting that a manager at her institution seems capable of combining the care of her children with a successful career, she implies that this is possible only with spousal support. She perceives it to be extremely difficult for a dual-career couple to care for children and suggests that generally one of the two partners has to sacrifice his/her career to support the career of the other and the care of children. This idea is also emphasised by the Dean in the extract below.

'It would be extremely difficult to do this job if I had a family. I would not have applied for the first dean position if I had children. You need to be as committed to the career as 
to your partner. Also, it is difficult for both partners to have a career; you are either committed to a career or you are committed to support one. I feel how heavy it would be to have a very demanding job and a family. ... It was hard for me to support my partner's activity when he asked me to proof read his articles and books and I had to do it before going to work in the morning.' (Mary, Dean)

Both this extract and the one below represent women managers as totally committed to their job. The women in the extracts above and below illustrate their career as a priority in their lives (both have chosen not to have children). These two academic-managers admit that since they moved away from their partners (both managers have relocated when they accepted their current position), they feel they can focus more on their career. The interviewee above suggests that it is extremely difficult for a dual-career couple to support each other, even when they do not have children. She implies that often one has to choose between pursuing his/her career and supporting the career of the partner.

For one of these women academic-managers, living in two locations has allowed her and her partner to find the space for their relationship, which is now confined to the weekends. The long distance from their partners has permitted these two academic-managers to focus totally on their demanding jobs during the week and dedicate the weekend to their private life. Jo, below, suggests that it would not be worth sacrificing the family for the job, one has to choose between either having a family or pursuing a career. She implies that her job is incompatible with having a family ('If I had wanted any [children] I would have had to reconsider my job’).

'I work from early in the mornings until late evening. With this job it is actually better for my personal life because my partner lives in xxx (a city approximately $220 \mathrm{Km}$ away) and now my weekends are for me. We see each other during the weekends and it works well. Before I was working all day and weekends as well, so now that we are separated it is better. I don't have children so that's not a problem, if I had wanted any I would have had to reconsider my job. If children are what you want it is not worth sacrificing the family for the job.' (Jo, Associate Dean) 
For those women who do not have children it is a choice to either have a career or a family. For the manager who has two children it is a matter of determination, family support and organisation. Susan (also an associate dean) admitted that outside work she has no time for other friendships as the family have to have all her spare time, which is limited. This issue was also raised by a senior woman academic at Oxbridge who suggested that the little extra time that she could afford outside work had to be spent with her family and this left no time for other activities (Powney, 1997). In the extract below, Susan outlines the importance of spousal and family support, organisation skills and the importance of collegial support within her work place.

'I don't have a personal life, I am either at work or mum at home. You need stamina to do this job, there is not intellectual or spiritual challenge. I work long hours and work from home when I can. I developed people that can support me, a team, I am a team player. I have grown up here, I could choose which people I would like to be involved with. I have a husband who supports me and cooks and put the dishwasher on and does help. My children are sensitive, they've never known anything else, their mum has always worked. They realise when I am busy and when they have to do their own things. They accept that having a busy mum also means that she can buy them whatever they want, all the material things and she is also a mum to be proud of, a deputy head of a university, or a big school as they say. And I have all the machines to help me with the house-work: washing machine, tumble dryer, dish washer, I do the shopping on the internet, I organise myself.' (Susan, Associate Dean)

Susan emphasises her relationships at work. She considers herself a team player, however, within her team, she locates herself at the top level with the power to choose and develop the people she likes and those who can support her. This is perceived by a male member of staff as manipulative. He suggested: 'she is very good and successful at her job, however she has the skill of turning things to her own advantage. I would not trust her, she is very instrumental'. Once again, a male academic represents a woman's success and achievements in negative terms. 


\section{Discussion and Conclusions}

The proportion of female academics in the UK is low compared to the proportion of men, with the proportion of higher ranking female academics, in both managerial and professorial careers, even lower. This study focuses on the unusual case of a business school, a traditionally masculine and male dominated academic institution, which is mostly managed by women. Interviews and observations of the workplace have highlighted more subtle, concealed and unconscious modes of connecting to gender relations and symbolism, than cases in which gender repression is revealed by numerical discrepancy.

At the organisation level, women's position in relation to management elicits conflicts and tensions over the masculine aspects of the academic culture and educes particular forms of resistance. Although both men and women refer to the symbolic discourse of the bossy woman manager to suggest that they do not like to work for a woman, the dominance of women managers has influenced women's work in encouraging them to apply for promotions and in feeling more confident about their contribution. It has also triggered a process in which men downplay women's achievements and attribute their success to the support they receive from the women managers. While the dominance of women managers creates tensions and ambiguities within the gendered dynamics of the organisation, it has been recognised by the academic staff that since the appointment of the female dean, the school has significantly improved in relation to aspects of research, quality processes, services offered to students and facilities available to students and staff. In the two departments headed by women, staff commented on the greater involvement, encouragement and support they receive.

In analysing women academic-managers' relationship to their managerial subject positions (Mouffe, 1995), it emerges that tensions are engendered over their (feminine) identities, over 
their identities as managers and over their (gendered) roles outside work. As Gherardi (1996: 190) suggests, women in traditionally male occupations often experience the position of being outsiders on the inside. 'The experience of being a stranger and entering a 'non-natural' culture ... entails the suspension of normal thought patterns' and the experience of contradictory positioning, regardless of hierarchical status.

In relation to patterns of identity construction, the analysis of the interviews has highlighted examples in which the women managers (and other academic staff) reiterate discourses associated with femininities (e.g. greater personal as well as professional support, more open and democratic communication) to preserve their feminine identities(Goode and Bagilhole, 1998; Priola, 2004). Conversely, they also deny some feminine attributes (e.g. emotional and soft) to demonstrate masculine qualities that fit in with the organisation and their managerial role (see also Priola, 2004). It appears that to position themselves as managers, these women enact more masculine behaviours, mainly aimed at rationally controlling their work environment and repressing their emotions. On the other hand, as women and as employees they recognise the need for emotional care and nurturing but fail to espouse their femininities, probably for a fear of loosing their authority. It is argued, that these contrasting positions may elicit unpredictable behaviours and sometimes anxiety concerning one’s competence, abilities and work relationships (Prichard and Deem, 1999; Gherardi, 1996).

Focusing on the tensions between their 'institutional' identities as managers and their personal identities as partners, and in some cases as mothers, these women academicmanagers seem to address the conflict they experience by attempting to separate their professional and personal roles (e.g. 'I am either at work or mum at home'). For the academic-managers who do not have children, confining a greater investment in their role as managers during the week and investing in their role as partners mainly during the weekend, has allowed them to reduce the conflicts and tensions they experienced when they were living with their partners. However, in both cases, the choice of separating professional from 
personal roles does not necessarily resolve the conflicts and contradictions they may experience.

As this study suggests, the increased presence of women managers may engender various reactions from men and women. However, it does not necessarily determine a feminine working environment; it can, on the contrary, create dynamics that reiterate the dominant masculine culture (Thomas and Davies, 2002). As acknowledged by Whitehead (2001: 97) 'to assume ... that an increase in women managers to some critical mass inevitably translates to predictable changes in organisational culture is to misunderstand the processes of work, both regarding identity formation and organisational life'. Nevertheless, this study does illustrates that women are not passive recipients of masculine practices and that their responses, while creating tensions and conflicts (at both organisational and personal level), may be generating some pockets of change (particularly at departmental level).

\section{Acknowledgements}

I wish to thank the women academic-managers and all academic staff who participated to this research. I would like to thank the anonymous reviewers for their rigorous and helpful comments on an earlier version of this work. 


\section{References}

Alvesson, M. (1998) Gender Relations and Identity at Work. A case study of Masculinities and Femininities in the Advertising Industry, Human Relations, 51(8), pp. 969-1005.

Alvesson, M. and Billing, Y. (1997) Understanding Gender and Organizations (London, Sage).

Association Of University Teachers (2004) The gender pay gap in UK higher education 2001-2 (AUT Research) http://www.aut.org.uk

Ball, S.J. (1990) Markets, morality and equality in education (London, Tufnell Press).

Barry, J., Chandler, J. and Clark, H. (2001) Between the ivory tower and the academic assembly line, Journal of Management Studies, 31(1), pp. 87-102.

Blackmore, J. (1996) Doing 'emotional labour' in the education market place: stories from the field of women and management, Discourse: Studies in the Cultural Politics of Education, 17(3), pp. 337-349.

Blackmore, J. and Sachs, J. (2001) Women Leaders in the Restructured University. In: A. Brooks and A. Mackinnon (Eds) Gender and the Restructured University (Buckingham, SRHE and Open University Press).

Brooks, A. (2001) Restructuring Bodies of Knowledge. In A. Brooks and A. Mackinnon (Eds) Gender and the Restructured University (Buckingham, SRHE and Open University Press).

Brooks, A. and Mackinnon, A. (2001) (Eds) Gender and the Restructured University (Buckingham, SRHE and Open University Press).

Calas, M.B. and Smircich, L. (1992) Using the "F" word: Feminist theories and the social consequences of organizational research. In: A.J. Mills and P. Tancred (Eds) Gendering Organizational Analysis (London, Sage).

Cockburn, C. (1991) In the Way of Women. Men's Resistance to Sex Equality in Organizations (London, Macmillan).

Collinson, D. and Hearn, J. (1996) (Eds) Men as Managers, Managers as Men. Critical Perspectives on Men, Masculinities and Managements (London, Sage).

Collinson, D. and Hearn, J. (1994) Naming Men as Men, Gender, Work and Organization, 1(1), pp. 1-22.

Deem, R. (2003) "Gender, Organisational Cultures and the Practices of Manager-Academics in UK Universities”, Gender, Work and Organization, 10(2), pp. 239-259.

Dines, E. (1993) Overview: women in higher education management. In: Women in Higher Education Management (Paris, Commonwealth secretariat and UNESCO).

Doyle Walton K. (1997) UK Women at the Very Top: An American Assessment. In: H. Eggins (Ed) Women as Leaders and Managers in Higher Education (Buckingham, SRHE and Open University Press).

Eggins, H. (1997) (Ed) Women as Leaders and Managers in Higher Education (Buckingham, SRHE and Open University Press).

El-Khawas, E. (1997) Foreword. In: H. Eggins (Ed) Women as Leaders and Managers in Higher Education (Buckingham, SRHE and Open University Press).

Ferguson, K.E. (1984) The Feminist Case Against Bureaucracy (Philadelphia PA, Temple University Press).

Fondas, N. (1997) Feminization unveiled: management qualities in contemporary writings, Academy of Management Review, 22(1), pp. 257-283.

Gherardi, S. (1994) The Gender We Think, The Gender We Do in our Everyday Organisational Lives, Human Relations, 47(6), pp. 591-610.

Gherardi, S. (1996) Gendered organisational cultures: narratives of women travellers in a male world, Gender, Work and Organization, 3(4), pp. 187-201.

Goode, J. and Bagilhole, B. (1998) Gendering the management of change in higher education: a case study, Gender, Work and Organization, 5(3), pp. 148-164.

Headlam-Wells, J. (2004) E-mentoring for aspiring women managers, Women in Management Review, 19(4), pp. 212-218. 
Hearn, J. (2001) Academia, Management and Men: Making the Connections, Exploring the Implications. In: A. Brooks and A. Mackinnon (Eds) Gender and the Restructured University (Buckingham, SRHE and Open University Press).

Hekman S.J. (1992) Gender and Knowledge: Elements of Postmodern Feminism (Cambridge, Polity).

Higher Education Statistics Agency (2003) Resources of Higher Education Institutions 2002/2003 (Cheltenham, HESA).

Irigaray, L. (1985) Speculum of the Other Woman (Ithaca, NY, Cornell University Press).

Joyner, K. and Preston, A. (1998) Gender differences in perceptions of leadership role, performance and culture in a university: a case study, International Review of Women and Leadership, 4(2), pp. 34-43.

Kanter, R.M. (1989) The new managerial work, Harvard Business Review, 67(6), pp. 85-92.

Kenway, J (1995) Marketing education: some critical issues (Geelong, Deakin University Press).

Kerfoot, D. (2000) Body Work: Estrangement, disembodiment and the Organizational 'other'. In: J. Hassard, R. Holliday and H. Willmott (Eds) Body and Organization (London, Sage).

Kerfoot, D. and Knights, D. (1993) Management, Masculinity and Manipulation: From Paternalism to Corporate Strategy in financial services, Journal of Management Studies, 30(4), pp. 659-677.

Kerfoot, D. and Knights, D. (1996) “The best is yet to come?” The quest for embodiment in managerial work. In: D.L. Collinson and J. Hearn (Eds), Men as Managers, Managers as Men. Critical Perspectives on Men, Masculinities and Management (London, Sage).

Kerfoot, D. and Knights, D. (1998) Managing Masculinity in Contemporary Organizational Life: A ‘Man’agerial Project, Organization, 5(1), pp. 7-26.

Kerman, L. (1995) The good witch: advice to women in management. In: L. Morley and V. Walsh (Eds) Feminist Academics: Creative Agents for Change (London, Taylor and Francis).

King, C. (1997) Through the Glass Ceiling: Networking by Women Managers in Higher Education. In: H. Eggins (Ed) Women as Leaders and Managers in Higher Education (Buckingham, SRHE and Open University Press).

Kristeva, J. (1981) Women can never be defined. In: E. Harkes (Ed), New French Feminism (New York, Schocken).

Korabik, K. (1990) Androgyny and leadership style, Journal of Business Ethics, April/May.

Korabik, K. and Ayman, R. (1990) Should women managers have to act like men? Journal of Management Development, 8(6).

Leathwood, C. (2005) 'Treat me as a human being-don't look at me as a woman': femininities and professional identities in further education, Gender and Education, 17(4), pp. 387409.

Leonard, P. (1998) Gendering change? Management, masculinity and the dynamics of incorporation, Gender and Education 10, pp. 71-84.

McCarthy, H. (2004) Girlfriends in High Places (London, Demos).

Middlehurst, R. (1997) Leadership, Women and Higher Education. In: H. Eggins (Ed), Women as Leaders and Managers in Higher Education (Buckingham, SRHE and Open University Press).

Miller, H. (1995) Management of Change in Universities: Australia, Canada and the United Kingdom. Association of Commonwealth Universities Bulletin of Current Documentation, 115, pp. 30-4.

Mills, A.J. and Tancred, P. (1992) (Eds) Gendering Organizational Analysis (London, Sage).

Mouffe, C. (1995) Feminism, citizenship and radical democratic politics. In: L. Nicholson and S. Seidman (Eds) Social Postmodernism: Beyond Identity Politics (Cambridge, Cambridge University Press).

Munford, R. and Rumball, S. (1999) Women, culture and powersharing. Unpublished conference paper. (Palmerston North, Massey University). 
Oakley, A. (2001) Foreword. In: A. Brooks and A. Mackinnon (Eds) Gender and the Restructured University (Buckingham, SRHE and Open University Press).

Oseen, C (1997) Luce Irigaray, sexual difference and theorising leaders and leadership, Gender, Work and Organization, 4(3), pp.170-184.

Parker, M. and Jary, D. (1995) The McUniversity: organisation, management and academic subjectivity, Organization, 2(2), 319-338.

Powney, J. (1997) On becoming and being a manager in education. In: H. Eggins (Ed), Women as Leaders and Managers in Higher Education (Buckingham, SRHE and Open University Press).

Prichard, C. (1996) Managing Universities: Is it Men's Work? In: D.L. Collinson and J. Hearn (Eds), Men as Managers, Managers as Men. Critical Perspectives on Men, Masculinities and Managements (London, Sage).

Priola, V. (2004) Gender and Feminine Identities. Women as Managers in a UK Academic Institution, Women in Management Review, 19(8), 421-430.

Rice, E. (1992) Towards a broader conception of scholarship: the American context. In: T. Winston and R. Geiger (Eds) Research and Higher Education (Buckingham, SRHE and Open University Press).

Slaughter, S. And Leslie, L. (1997) Academic Capitalism: Politics, Policies and the Entrepreneurial University (Baltimore, Johns Hopkins University Press).

Spurling, A. (1997) Women and change in higher education. In: H. Eggins (Ed), Women as Leaders and Managers in Higher Education (Buckingham, SRHE and Open University Press).

Stern, S. (2004) Look out boys, it's time for the girls' club, Financial Times, 13 September 2004, p.7.

Thomas, R. and Davies, A. (2002) Gender and New Public Management: Reconstituting Academic Subjectivities, Gender, Work and Organization, 9(4), pp. 372-397.

Vinnicombe, S. and Colwill, N.L. (1995) The Essence of Women in Management (Harlow, Prentice-Hall).

Vinnicombe, S. and Singh, V. (2003) Locks and Keys to the Boardroom, Women in Management Review, 18(6), 325-333.

Whitehead, S. (2001) Woman as Manager: A Seductive Ontology, Gender, Work and Organization, 8(1), pp. 84-107.

Willmott, H. (1995) Managing the Academics: Commodification and Control in the Development of University Education in the U.K. Human Relations, 48(9), pp. 9931027. 
TABLE I: Gender distribution of Full-time Academic staff in all UK institutions 2002/2003.

\begin{tabular}{|c|c|c|c|c|c|}
\hline & \multicolumn{4}{|c|}{ Location of Institution } & \multirow[t]{2}{*}{ Total } \\
\hline & England & Wales & Scotland & $\begin{array}{c}\text { Northern } \\
\text { Ireland } \\
\end{array}$ & \\
\hline All full time staff & 97345 & 5825 & 14585 & 3045 & 120800 \\
\hline FEMALE & 34315 & 1990 & 5040 & 1065 & 42410 \\
\hline $\begin{array}{l}\text { Wholly institutionally } \\
\text { financed }\end{array}$ & 20850 & 1425 & 2720 & 735 & 25730 \\
\hline $\begin{array}{l}\text { Other sources of } \\
\text { finance }\end{array}$ & 13465 & 565 & 2320 & 330 & 16680 \\
\hline MALE & 63025 & 3835 & 9545 & 1980 & 78385 \\
\hline $\begin{array}{l}\text { Wholly institutionally } \\
\text { financed }\end{array}$ & 43680 & 3055 & 6555 & 1500 & 54790 \\
\hline 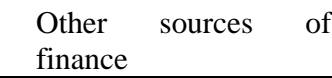 & 19345 & 780 & 2990 & 480 & 23595 \\
\hline
\end{tabular}

Source: HESA (2003), Resources of Higher Education Institutions 2002/2003. 
TABLE II: Academic staff gender pay gap 2001/2002 (based on average salary)

\begin{tabular}{l|ccccc} 
& \multicolumn{5}{|c}{ Location of Institution } \\
\cline { 2 - 6 } & $\begin{array}{l}\text { England } \\
(14.7 \%)\end{array}$ & $\begin{array}{l}\text { Wales } \\
(18 \%)\end{array}$ & $\begin{array}{c}\text { Scotland } \\
(17.5 \%)\end{array}$ & $\begin{array}{c}\text { Northern } \\
\text { Ireland } \\
(16.9 \%)\end{array}$ & $\begin{array}{c}\text { UK } \\
\mathbf{( 1 5 . 2 \% )}\end{array}$ \\
\hline Female & 29,708 & 28,156 & 28,831 & 29,116 & $\mathbf{2 8 , 9 5 3}$ \\
Male & 33,975 & 33,823 & 33,619 & 35,127 & $\mathbf{3 4 , 1 3 5}$ \\
\hline
\end{tabular}

Source: AUT (2004) based on HESA data.

\footnotetext{
${ }^{1}$ The term new university refers to a post-1992 university, an institution which, before 1992 was a polytechnic and was reclassified as university following The Further and Higher Education Act.

${ }^{2}$ The process of feminisation refers to the spread to organisational practices of values, meanings and behaviours culturally associated to females (e.g. nurturing and caring, interpersonal sensitivity and preference for open and collaborative relationships) (Kanter, 1989, Fondas, 1997). By using the generic term 'feminisation', I do not wish to imply that it refers to one femininity and to one mode of being feminine. Femininities (and masculinities) are regarded as contingent, fragmented and socially constructed gendered identities and practices.

${ }^{3}$ In the 1990s in Australia, as in many western countries such as the UK and the US, academic work has moved toward what Slaughter and Leslie (1997) define 'academic capitalism'.

${ }^{4}$ Since this research was conducted in 2002 the two female Associate Deans left and were replaced by men. Also, one of the female heads of department left and was replaced by another woman.

${ }^{5}$ To preserve confidentiality the names of the participants are pseudonyms.

${ }^{6}$ Vinnicombe and Singh (2003) suggest that women who have a mentor do better, as they gain reflected power, feedback, and access to resources and senior managers through their mentors. When women have been successful, one of the contributory factors that they report is the access to mentoring (Headlam-Wells, 2004). Furthermore, mentoring success breeds commitment to broadening mentoring opportunities.

7 Vinnicombe and Colwill (1995) discussed three types of women's network: professional and occupational networks (e.g. women in management), in-company networks (could be formal or informal groupings within a particular organisation and are open to women from a particular level) and training networks (grew out of women's training). Some women's networks provide workshops and training programmes and support their members with directories of members, role models and mentoring initiatives. A report into more than 20 women's networks was carried out by the think-tank Demos (McCarthy, 2004), and found that more structured networks were particularly beneficial to women, particularly those that operated during working time with the endorsement of employing organisations. The potential for women-only networks to make a real difference to women's access to managerial jobs is also evidenced by the results of a network initiative in General Electric (Stern, 2004). When the network began in 1998, only six per cent of middle management posts in the company were held by women. In 2004, it had reached over $12 \%$.
} 